\title{
ANALISIS PENGARUH PENGGUNAAN MEDIA BARU TERHADAP POLA INTERAKSI SOSIAL ANAK DI KABUPATEN SUKOHARJO
}

\author{
Agus Efendi, Puwani Indri Astuti, dan Nuryani Tri Rahayu \\ Universitas Veteran Bangun Nusantara Sukoharjo \\ J1. Letjend. Sujono Humardani No. 1 Jombor, Sukoharjo 57521 \\ Telp. 0271593156 Faks. 0271591065 \\ kambang.leng2@yahoo.co.id; indripuspo@gmail.com
}

\begin{abstract}
ABSTRAK
Penelitian ini bertujuan untuk menganalisis dan mendeskripsikan penggunaan media digital oleh anak, pola interaksi sosial anak, dan pengaruh penggunaan media baru terhadap sosiabilitas anak di Kabupaten Sukoharjo. Jenis penelitian ini adalah eksplanatif korelasi kausal dengan metode survei menggunakan instrumen utama kuesioner. Populasi adalah anak usia 8-12 tahun murid Sekolah Dasar atau sederajat di Kabupaten Sukoharjo yang berjumlah 11.263 siswa dan tersebar di 554 SD dan MI. Jumlah sampel sebanyak 80 siswa. Hasil penelitian menunjukkan bahwa tingkat penggunaan media baru di kalangan anak usia 8-12 tahun di Kabupaten Sukoharjo dalam kategori sedang $(1,89)$ dan interaksi sosialnya dalam kategori tinggi $(2,45)$. Asumsi yang menyatakan bahwa semakin tinggi penggunaan media baru maka interaksi sosial anak akan cenderung semakin rendah dapat diterima kebenarannya dengan koefisien korelasi sebesar 0,54 pada derajat kebebasan 0,05 atau tingkat kepercayaan $95 \%$.
\end{abstract}

Kata Kunci: media baru, interaksi sosial, sosiabilitas, siswa SD

\section{ABSTRACT}

This study aims at analyzing and describing the use of digital media by elementary school students, the pattern of social interaction of the students and the influence of new media use on the students' social ability. This research is explanative and has causal correlation with survey method using main instrument of questionnaire. The population covers students aged 8-12 years of elementary school students of Sukoharjo regency with total number 11.263 children fromn 554 elementary schools. The sample size is 80 students. The results showed that the rate of use of new media among the children was in the medium category (1.89), and social interaction in high category (2.45). The assumption which states that the higher the use of new media the social interaction of children tends to be lower is acceptable. It was proved with a correlation coefficient of 0.54 at degrees of freedom 0.05 or $95 \%$ confidence level.

Keywodrs: digital media, social interaction, sociability, elementary school students

\section{PENDAHULUAN}

Kemajuan teknologi saat ini telah melahirkan banyak bentuk media baru dalam komunikasi yang berbasis komputer, internet, dan sistem digital seperti telepon seluler (handphone), surat elektronik, mesin faksimile, televisi, radio streaming, dan berbagai perangkat serta program jejaring sosial lain. Berbagai perangkat atau media komunikasi tersebut saat ini telah banyak digunakan oleh anak-anak. Data statistik yang dikeluarkan oleh NPD Group tentang 
penggunaan digital media oleh anak-anak umur 2-14 tahun memperlihatkan peningkatan yang signifikan dalam penggunaan video games, komputer, dan digital music player oleh anak-anak di tahun 2008.

Berbagai teknologi komunikasi pada dasarnya diciptakan untuk membuat hidup manusia menjadi semakin mudah dan nyaman, tetapi perangkat tersebut digunakan oleh khalayak dengan berbagai motivasi dan kepentingan sehingga tidak jarang menimbulkan dampak buruk yang tidak diinginkan. Sekalipun belum ada pembuktian secara ilmiah, bahwa maraknya perilaku sosial menyimpang adalah akibat penyalahgunaan teknologi media komunikasi namun suatu kenyataan bahwa kedua fenomena tersebut terjadi pada waktu yang bersamaan. Saat ini banyak dijumpai adanya siswa sekolah dasar (SD) dengan usia antara 6-12 tahun yang sudah mahir mengoperasikan dan memiliki berbagai bentuk media baru. Data Yayasan Pengembangan Media Anak (YPMA) tahun 2010 menyebutkan bahwa anak-anak di Indonesia menonton TV sekitar 7-8 jam per hari (YPMA, 2010:17). Maraknya penggunaan media baru oleh anak-anak dapat berpengaruh terhadap perilakunya, termasuk dalam hubungannya dengan orang tua, anggota keluarga lain, teman sekolah, teman bermain, dan orang lain di sekitarnya. Theresa Orange dan Louise O'Flynn dalam buku The Media Diet for Kids (2005) menyebutkan beberapa perilaku yang didapat dari penggunaan TV antara lain perilaku anti sosial, apatis, anak mengetahui seks secara samar-samar, dewasa dini, dan terjadinya ketidakseimbangan energi.

Kondisi tersebut juga dapat dijumpai di berbagai wilayah di Indonesia, ketika media baru sudah menjangkau anak-anak, baik yang ada di kota-kota besar maupun yang jauh di pelosok pedesaan. Hasil observasi di tiga SD di Kecamatan Bendosari Kabupaten Sukoharjo menunjukkan bahwa lebih dari 70\% anak yang berusia 6-12 tahun telah mengenal, memiliki, dan mampu mengoperasikan sedikitnya 2 macam media baru. Berdasarkan fenomena tersebut, penelitian ini memfokuskan kajian pada penggunaan media baru dan pola interaksi sosial di kalangan anak-anak usia 8-12 tahun di Kabupaten Sukoharjo dengan asumsi bahwa penggunaan media baru berpengaruh signifikan terhadap pola interaksi sosial anak usia 8-12 tahun. Ketika anak-anak yang tingkat penggunaan medianya tinggi, interaksi sosialnya bersifat tak langsung atau bermedia, sosiabilitasnya cenderung rendah, kepekaan sosialnya cenderung rendah, cenderung agresif, lebih mengutamakan isi ketimbang relasi dalam berkomunikasi, dan cenderung egaliter.

Media baru (new media) adalah sebuah terminologi untuk menjelaskan konvergensi antara teknologi komunikasi digital yang terkomputerisasi serta terhubung ke dalam jaringan. Media baru adalah segala sesuatu yang dapat menyalurkan informasi (perantara) dari sumber informasi kepada penerima informasi. "Media baru memiliki dua unsur utama yakni digitalisasi dan konvergensi. Internet merupakan bukti konvergensi karena menggabungkan beberapa fungsi media lain seperti audio, video, dan teks“" (McQuail's, 2006:26). Berikut ini adalah contoh teknologi yang termasuk media baru yaitu: (a) Internet dan website, (b) Televisi digital/ plasma TV, (c) Digital cinema/3D cinema, (d) Superkomputer/laptop, (e) DVD/CD/blue ray, (f) MP3 player, (g) Ponsel/PDA phone, (h) Video game, (i) RSS feed, (j) Streaming Video, dan lain-lain (Kompasiana, 2010). Sebagian besar teknologi yang digambarkan sebagai "media baru" bersifat digital, integratif, interaktif, dapat dimanipulasi, serta bersifat jaringan, padat, mampat, dan tidak memihak.

Manfaat media baru adalah memudahkan seseorang untuk memperoleh suatu hal yang diinginkannya, seperti: (a) arus informasi yang dapat dengan mudah dan cepat diakses di mana saja dan kapan saja, (b) sebagai media transaksi jual beli, (c) sebagai media hiburan, contohnya game online, jejaring sosial, streaming video, dan lain-lain, (d) sebagai media komunikasi yang efisien, (e) sarana pendidikan dengan adanya buku digital (Kompasiana, 
2010). Khalayak menggunakan media untuk memenuhi berbagai kebutuhan dan kepentingan sehingga dapat dikatakan bahwa penggunaan media oleh khalayak berorientasi pada tujuan. Teori uses and gratification berasumsi bahwa "khalayak pada dasarnya bersifat aktif, selektif dan goal oriented dalam menggunakan media untuk memenuhi kebutuhan dan kepentingannya. Media massa berkompetisi dengan sumber-sumber lainnya (saluran komunikasi antar pribadi, kelompok, organisasi, dan sebagainya) dalam upaya memenuhi kebutuhan dan kepentingan khalayak" (Rosengren et al., dalam Effendy, 2000: 291). Kerangka konseptual model uses and gratification secara sederhana dapat digambarkan sebagai berikut:

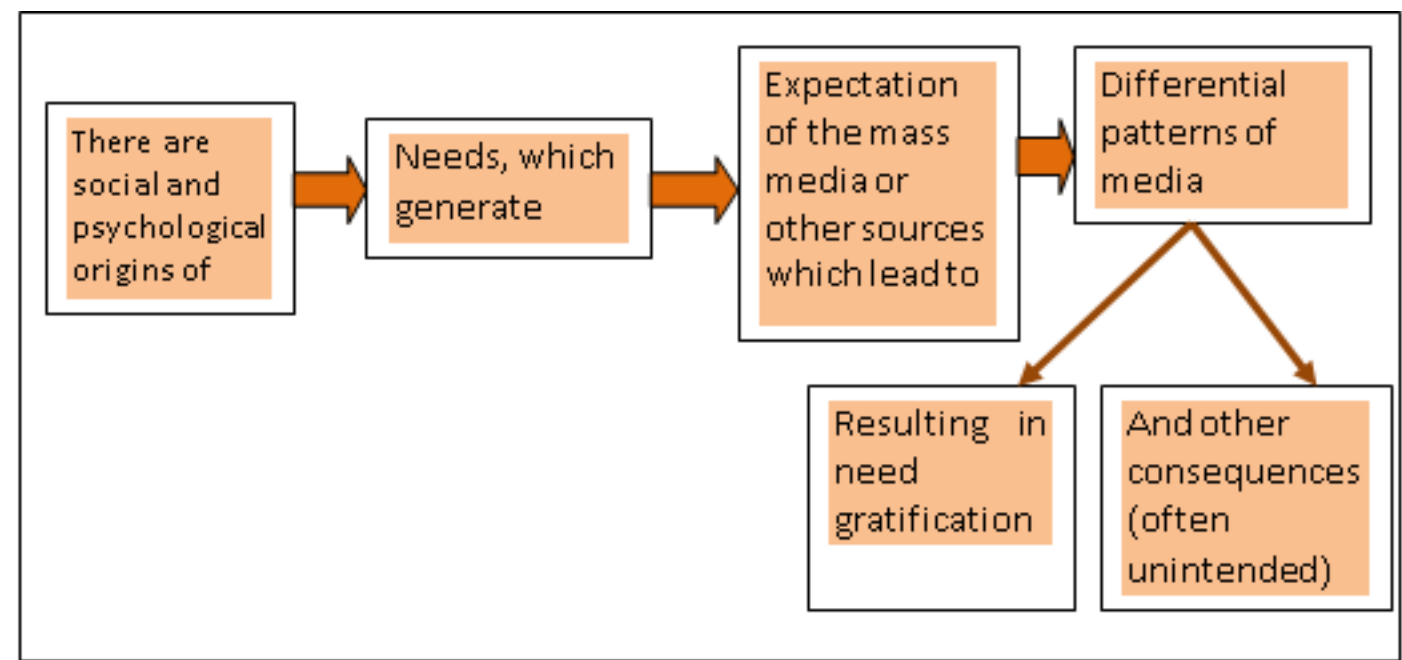

Gambar 1. Model penggunaan dan kepuasan Penggunaan media oleh khalayak dapat diukur dari jumlah jenis media yang

Frank Biocca dalam Littlejohn (1999:337) menyatakan bahwa karakteristik eksposur atau terpaan media dapat diukur melalui dimensi-dimensi berikut:

1. Selectivity (kemampuan memilih) yaitu kemampuan audience dalam menetapkan pilihan terhadap media dan isi yang akan dieksposenya.

2. Intentionally (kesengajaan) yaitu tingkat kesengajaan audience dalam menggunakan media atau kemampuan dalam mengungkapkan tujuan-tujuan penggunaan media.

3. Utilitarianism (pemanfaatan) yaitu kemampuan audience untuk mendapatkan manfaat dari penggunaan media.

4. Involvement (keterlibatan) yaitu keikutsertaan pikiran dan perasaan audience dalam menggunakan media dan pesan media yang diukur dari frekuensi maupun intensitas.

5. Previous to influence, yaitu kemampuan untuk melawan arus pengaruh media.

Teori penggunan media menunjukkan bahwa lahirnya media baru dapat menciptakan bentuk-bentuk interaksi sosial yang berbeda dengan sebelumnya. Interaksi pada dasarnya merupakan proses peyesuaian diri terhadap lingkungan sosial, bagaimana seharusnya seseorang hidup di dalam kelompoknya, baik di dalam kelompok kecil maupun kelompok masyarakat luas. Interaksi seseorang dengan manusia lain terjadi sejak bayi lahir dan terus berkembang sepanjang kehidupanya. Menurut Piaget dalam Rahayu (2009), interaksi sosial anak pada tahun pertama sangat terbatas, terutama hanya dengan ibunya, perilakunya bersifat egosentric, belum banyak memperhatikan lingkunganya sehingga apabila kebutuhan dirinya telah terpenuhi maka tidak peduli lagi dengan lingkunganya. Pada umur-umur selanjutnya, anak mulai belajar mengembangkan interaksi sosial dengan belajar menerima kelompok (masyarakat), memahami tanggung jawab, dan berbagai pengertian dengan orang lain. Menginjak masa remaja interaksi 
dan pengenalan atau pergaulan dengan teman sebaya terutama lawan jenis, menjadi semakin penting. Pada akhirnya pergaulan sesama manusia menjadi suatu kebutuhan (Sarwono, dalam Rahayu, 2009: 31).

Dengan demikian dapat dikatakan bahwa hubungan sosial(sosialisasi) merupakan hubungan antarmanusia (interaksi sosial) yang saling membutuhkan mulai dari tingkat sederhana dan terbatas hingga yang amat kompleks. Interaksi sosial diartikan sebagai hubungan-hubungan sosial yang dinamis yang menyangkut hubungan antara orang-orang perorangan, antara kelompok-kelompok manusia, maupun antara orang perorangan dengan kelompok manusia. Faktor yang mendasari berlangsungnya interaksi sosial baik secara tunggal maupun secara bersamaan adalah imitasi, sugesti, identifikasi, dan simpati. Interaksi sosial dikategorikan ke dalam dua bentuk, yaitu yang bersifat asosiatif dan disosiatif (Soekanto, 2001:67-77). Interaksi sosial yang bersifat asosiatif, yakni hubungan antar individu yang mengarah kepada bentukbentuk asosiasi (hubungan atau gabungan) seperti (a) kerja sama, yaitu suatu usaha bersama antara orang perorangan atau kelompok untuk mencapai tujuan bersama, (b) akomodasi, yaitu suatu proses penyesuaian sosial dalam interaksi antara pribadi dan kelompok-kelompok manusia untuk meredakan pertentangan, (c) asimilasi, yaitu proses sosial yang timbul bila ada kelompok masyarakat dengan latar belakang kebudayaan yang berbeda, saling bergaul secara intensif dalam jangka waktu lama sehingga lambat laun kebudayaan asli mereka akan berubah sifat dan wujudnya membentuk kebudayaan baru sebagai kebudayaan campuran, dan (d) akulturasi, yaitu proses sosial yang timbul, apabila suatu kelompok masyarakat manusia dengan suatu kebudayaan tertentu dihadapkan dengan unsur-unsur dari suatu kebudayaan asing sedemikian rupa sehingga lambat laun unsur-unsur kebudayaan asing itu diterima dan diolah ke dalam kebudayaan sendiri, tanpa menyebabkan hilangnya kepribadian dari kebudayaan itu sendiri. Sedang interaksi sosial yang bersifat disosiatif meliputi (a) Persaingan, yaitu suatu perjuangan yang dilakukan perorangan atau kelompok sosial tertentu agar memperoleh kemenangan atau hasil secara kompetitif, tanpa menimbulkan ancaman atau benturan fisik di pihak lawannya, (b) Kontravensi adalah bentuk proses sosial yang berada di antara persaingan dan pertentangan atau konflik, dan (c) Konflik adalah proses sosial antar perorangan atau kelompok masyarakat tertentu, akibat adanya perbedaan paham dan kepentingan yang sangat mendasar.

\section{METODE}

Penelitian ini termasuk ke dalam jenis penelitian eksplanatif korelasional atau penelitian yang dimaksudkan untuk menjelaskan hubungan antar variabel dan membuat generalisasi. Sementara itu, strategi yang digunakan adalah strategi penelitian kuantitatif yaitu penelitian yang lebih menekankan analisisnya pada numerikal (angka) yang diolah dengan metode statistika (Singarimbun dan Sofyan Effendi, 1995:3). Lokasi penelitian dilakukan di Kabupaten Sukoharjo. Data yang dianalisis meliputi data primer dan data sekunder yang bersifat kuantitatif dan kualitatif. Data primer berupa data mengenai penggunaan media baru dan interaksi sosial yang diperoleh langsung dari sumber pertama yaitu anak usia 8-12 tahun sebagai responden. Data sekunder berupa data mengenai ketersediaan media baru, data demografis, data geografis, dan data pendukung lain diperoleh dari dokumen, arsip, atau catatan lainnya. Populasi berupa anak usia 8-12 tahun atau murid Sekolah Dasar dan Madrasah Ibtidaiyah di Kabupaten Sukoharjo yang berjumlah 11.263 orang dan tersebar di 554 SD dan MI. Sampel ditetapkan dengan menggunakan teknik multi stage cluster sampling atau sampel berjenjang secara proporsional dan random (Arikunto, 2006:134). Jumlah sampel akhir sebanyak 80 siswa yang tersebar di 38 SD/Madrasah Ibtidaiyah di Sukoharjo. Teknik pengumpulan data menggunakan survei dengan instrumen kuesioner dan observasi nonpartisipatif yaitu pengamatan tanpa keterlibatan langsung peneliti dalam situasi yang diamati (Soekanto, 2001:49). Reliabilitas 
instrumen ditentukan dengan validitas konstruk atau "kerangka dari suatu konsep dan diuji dengan rumus korelasi Product Moment" (Singarimbun, 1995:124). Teknik analisis data meliputi analisis univariat (deskriptif), analisis bivariat (tes statistik korelasi Rank Sperman), uji hipotesis dan uji signifikansi (uji T) melalui vasilitas SPSS versi 18.0.

\section{HASIL DAN PEMBAHASAN}

Penelitian mengenai pengaruh penggunaan media baru terhadap pola interaksi sosial anak ini berlokasi di Kabupaten Sukohajo. Oleh karena itu, sebelum mendeskripsikan berbagai temuan yang diperoleh, terlebih dahulu akan dideskripsikan kondisi umum Kabupaten Sukoharjo sebagai setting penelitian.

Kabupaten Sukoharjo terbagi dalam 12 kecamatan, 150 desa, 17 kelurahan, 2.026 dukuh, 1.438 rukun warga, dan 4.428 rukun tetangga. Batas wilayahnya adalah:

1. Utara berbatasan dengan Kota Surakarta dan Kabupaten Karanganyar.

2. Timur berbatasan dengan Kabupaten Karanganyar.

3. Selatan berbatasan dengan Kabupaten Gunung Kidul dan Kabupaten Wonogiri.

4. Barat berbatasan dengan Kabupaten Boyolali dan Kabupaten Klaten.

Jumlah penduduk Kabupaten Sukoharjo sebanyak 827.083 jiwa yang terdiri dari 416.178 jiwa perempuan dan 410.905 jiwa laki-laki. Sarana pendidikan yang dimiliki antara lain Taman Pendidikan Anak Usia Dini (PAUD), Sekolah Dasar Luar Biasa (SDLB), Sekolah Menengah Pertama Luar Biasa (SMPLB), Sekolah Menengah Atas Luar Biasa (SMALB), Taman KanakKanak (TK), Sekolah Dasar (SD), Sekolah Lanjutan Tingkat Pertama (SLTP), Sekolah Lanjutan Tingkat Atas (SLTA), dan Perguruan Tinggi (PT).

Jumlah Sekolah Dasar di Kabupaten Sukoharjo sebanyak 481 dengan jumlah siswa sebanyak 61.963 orang. Jumlah Madrasah Ibtidaiyah sebanyak 74 dengan jumlah siswa sebanyak 13.167 orang. Jumlah guru yang mengajar di SD/SDLB/MI sebanyak 4.903 orang dengan rincian 4.413 orang mengajar di sekolah negeri dan 490 lainnya di sekolah swasta. Hampir seluruh anak usia sekolah dasar dapat menempuh pendidikan sebagaimana ditunjukkan oleh angka partisipasi penduduk dalam pendidikan sebesar $115,78 \%$ untuk angka partisipasi kasar dan sebesar 99,52\% untuk angka partisipasi murni.

Tabel 1 Jumlah SD/MI dan siswa di Kabupaten Sukoharjo tahun 2015

\begin{tabular}{clcc}
\hline No. & \multicolumn{1}{c}{ Jenis Sekolah } & Jumlah Sekolah & Jumlah Siswa \\
\hline 1. & Sekolah Dasar (SD) & 481 & 60.287 \\
2. & Madrasah Ibtidaiyah (MI) & 74 & 5.200 \\
\hline & Jumlah & 555 & 580.287 \\
\hline
\end{tabular}

Sumber: Dinas Pendidikan Kab. Sukoharjo 2015

Sejumlah sekolah tersebut terdiri dari sekolah negeri dan swasta yang tersebar di 12 kecamatan dengan rata-rata jumlah SD/MI tiap kecamatan sebanyak 46 sekolah dengan persebaran berkisar 35 (di Kecamatan Bulu) hingga 55 (di 3 kecamatan, yaitu Weru, Sukoharjo, dan Kartasura). Distribusi SD/MI tiap kecamatan sebagai berikut.

Tabel 2 Jumlah SD dan MI menurut status dan kecamatan di Kabupaten Sukoharjo tahun 2014

\begin{tabular}{ccccccc}
\hline \multirow{2}{*}{ No. } & \multirow{2}{*}{ Kecamatan } & \multicolumn{4}{c}{ Madrasah Ibtidaiyah } & \multicolumn{2}{c}{ Sekolah Dasar } & \multirow{2}{*}{ Jumlah } \\
\cline { 3 - 6 } & & Negeri & Swasta & Negeri & Swasta & \\
\hline 1 & Weru & 1 & 12 & 42 & 0 & 55
\end{tabular}




\begin{tabular}{|c|c|c|c|c|c|c|}
\hline 2 & Bulu & 0 & 0 & 34 & 1 & 35 \\
\hline \multirow{2}{*}{ No. } & \multirow{2}{*}{ Kecamatan } & \multicolumn{2}{|c|}{ Madrasah Ibtidaiyah } & \multicolumn{2}{|c|}{ Sekolah Dasar } & \multirow{2}{*}{ Jumlah } \\
\hline & & Negeri & Swasta & Negeri & Swasta & \\
\hline 3 & Tawangsari & 0 & 6 & 35 & 0 & 41 \\
\hline 4 & Sukoharjo & 2 & 6 & 45 & 2 & 55 \\
\hline 5 & Nguter & 0 & 3 & 37 & 0 & 40 \\
\hline 6 & Bendosari & 1 & 9 & 37 & 1 & 48 \\
\hline 7 & Polokarto & 0 & 10 & 43 & 2 & 55 \\
\hline 8 & Mojolaban & 0 & 3 & 46 & 2 & 51 \\
\hline 9 & Grogol & 1 & 1 & 38 & 7 & 46 \\
\hline 10 & Baki & 1 & 5 & 29 & 2 & 37 \\
\hline 11 & Gatak & 0 & 6 & 29 & 1 & 36 \\
\hline \multirow[t]{2}{*}{12} & Kartasura & 0 & 7 & 41 & 7 & 55 \\
\hline & Jumlah & 6 & 68 & 456 & 25 & 555 \\
\hline
\end{tabular}

Sumber: Badan Pusat Statistik Kabupaten Sukoharjo 2015

Berdasar data tersebut dapat diketahui rata-rata siswa tiap sekolah sebanyak 135 orang, namun jumlah tersebut tidak terdistribusi secara merata dan lebih dominan di sekolah negeri.

Tabel 3 Jumlah kelas, murid, dan guru SD dan MI menurut kecamatan di Kabupaten Sukoharjo tahun 2014

\begin{tabular}{|c|c|c|c|c|c|c|c|}
\hline \multirow{2}{*}{ No. } & \multirow{2}{*}{ Kecamatan } & \multirow{2}{*}{ Kelas } & \multicolumn{2}{|c|}{ Murid } & \multicolumn{2}{|c|}{ Guru } & \multirow{2}{*}{ Rasio } \\
\hline & & & SD & MI & Negeri & Swasta & \\
\hline 1 & Weru & 375 & 3226 & 1573 & 419 & 0 & 12,80 \\
\hline 2 & Bulu & 250 & 2787 & 0 & 284 & 28 & 11,15 \\
\hline 3 & Tawangsari & 265 & 3403 & 859 & 322 & 0 & 16,08 \\
\hline 4 & Sukoharjo & 415 & 7516 & 2831 & 469 & 27 & 24,93 \\
\hline 5 & Nguter & 249 & 3223 & 629 & 312 & 0 & 15,47 \\
\hline 6 & Bendosari & 345 & 3736 & 1192 & 361 & 37 & 14,28 \\
\hline 7 & Polokarto & 360 & 5582 & 1531 & 394 & 32 & 19,76 \\
\hline 8 & Mojolaban & 327 & 6991 & 277 & 439 & 36 & 22,23 \\
\hline 9 & Grogol & 361 & 8391 & 596 & 382 & 105 & 24,89 \\
\hline 10 & Baki & 276 & 4369 & 1646 & 297 & 54 & 21,79 \\
\hline 11 & Gatak & 228 & 3589 & 567 & 291 & 7 & 18,23 \\
\hline \multirow[t]{2}{*}{12} & Kartasura & 428 & 9150 & 1466 & 443 & 169 & 24,80 \\
\hline & Jumlah & 3.879 & 61.963 & 13.167 & 4.413 & 495 & 19,37 \\
\hline
\end{tabular}

Sumber: Dinas Pendidikan Kabupaten Sukoharjo 2015

Dari tabel di atas dapat diketahui kepadatan rata-rata tiap kelas sebesar 19,37 atau 77,48\% kapasitas kelas. Daya tampung ruangan kelas rata-rata mencapai 25 orang sehingga masih terdapat sekitar 22,52\% ruangan yang masih dapat diberdayakan atau difungsikan secara maksimal. Secara ekonomis, sebagian siswa SD/MI di Kabupaten Sukoharjo berasal dari keluarga golongan ekonomi menengah ke bawah dan sebagian kecil dari golongan ekonomi 
atas. Hal ini wajar karena orang tua siswa yang masih duduk di bangku SD/MI rata-rata adalah keluarga muda yang belum mencapai puncak karier atau kesuksesan usaha.

Tabel 4 Kategori variabel independen: tingkat penggunaan media baru

\begin{tabular}{|c|c|c|c|c|c|c|c|c|c|}
\hline \multirow{3}{*}{ No. } & \multirow{3}{*}{ Indikator } & \multicolumn{6}{|c|}{ Kategori } & \multirow{3}{*}{ Rerata } & \multirow{3}{*}{ Kategori } \\
\hline & & \multicolumn{2}{|c|}{ Tinggi } & \multicolumn{2}{|c|}{ Sedang } & \multicolumn{2}{|c|}{ Rendah } & & \\
\hline & & $\mathbf{F}$ & $\%$ & $\mathbf{F}$ & $\%$ & $\mathbf{F}$ & $\%$ & & \\
\hline $\mathbf{A}$ & Selektifitas: & & & & & & & & \\
\hline 1 & $\begin{array}{l}\text { Ketersediaan media baru bagi } \\
\text { anak di rumah }\end{array}$ & 20 & 25 & 28 & 35 & 32 & 40 & 1,85 & Sedang \\
\hline 2 & Jumlah media yang digunakan & 25 & 31,25 & 38 & 47,5 & 17 & 21,25 & 2,1 & Sedang \\
\hline 6 & Jumlah acara TV yang disukai & 11 & 13,75 & 33 & 41,3 & 36 & 45 & 1,69 & Sedang \\
\hline 7 & $\begin{array}{l}\text { Jumlah media sosial yang } \\
\text { digunakan }\end{array}$ & 8 & 10 & 26 & 32,5 & 46 & 57,5 & 1,53 & Rendah \\
\hline 11 & $\begin{array}{l}\text { Jumlah handphone pribadi } \\
\text { yang dimiliki }\end{array}$ & 11 & 13,75 & 14 & 17,5 & 55 & 68,75 & 1,45 & Rendah \\
\hline 12 & Jenis handphone yang dimiliki & 16 & 20 & 33 & 41,3 & 31 & 38,75 & 1,81 & Sedang \\
\hline B & Intentionally: & & & & & & & & \\
\hline 3 & Penyediaan waktu khusus & 47 & 58,75 & 19 & 23,8 & 14 & 17,5 & 2,41 & Tinggi \\
\hline $\mathrm{C}$ & Utilitarianism: & & & & & & & & \\
\hline 5 & Tujuan menonton acara TV & 8 & 10 & 28 & 35 & 44 & 55 & 1,55 & Rendah \\
\hline 8 & $\begin{array}{l}\text { Tujuan penggunaan } \\
\text { handphone }\end{array}$ & 30 & 37,5 & 45 & 56,3 & 5 & 6,25 & 2,31 & Sedang \\
\hline 9 & $\begin{array}{l}\text { Tujuan penggunaan laptop } \\
\text { atau PC }\end{array}$ & 7 & 8,75 & 24 & 30 & 49 & 61,25 & 1,48 & Rendah \\
\hline 10 & Tujuan mengakses internet & 15 & 18,75 & 43 & 53,8 & 22 & 27,5 & 1,91 & Sedang \\
\hline 13 & $\begin{array}{l}\text { Tujuan penggunaan media } \\
\text { sosial }\end{array}$ & 24 & 30 & 27 & 33,8 & 29 & 36,25 & 1,94 & Sedang \\
\hline$D$ & Involvement: & & & & & & & & \\
\hline 4 & $\begin{array}{l}\text { Jumlah waktu menggunakan } \\
\text { media }\end{array}$ & 56 & 70 & 18 & 22,5 & 6 & 7,5 & 2,63 & Tinggi \\
\hline$E$ & Previous to influence: & & & & & & & & \\
\hline 14 & $\begin{array}{l}\text { Perasaan jika tidak mengakses } \\
\text { media }\end{array}$ & 22 & 27,5 & 23 & 28,8 & 35 & 43,75 & 1,84 & Sedang \\
\hline & $\begin{array}{l}\text { Jumlah rerata seluruh } \\
\text { indikator }\end{array}$ & & & & & & & 26,49 & \\
\hline & Rerata varibel & & & & & & & 1,89 & Sedang \\
\hline
\end{tabular}

Sumber: Kuesioner No. 1 - 14 yang telah diolah

\section{Penggunaan Media Baru oleh Anak Usia 8-12 Tahun di Kabupaten Sukoharjo}

Media baru (new media) yang memiliki definisi "unique forms of digital media, and the remaking of more traditional media forms to adopt and adapt to the new media technologies" (Flew; 2005:3). Media baru adalah segala sesuatu yang berbasis internet dan teknologi digital, seperti handphone/smartphone berikut seluruh fiturnya, media sosial, kamera digital, DVD/ CD player, radio-net, videogame, file sharing software, serta seluruh aktivitasnya mulai dari 
memotret, mengirimkan e-mail, SMS, file sharing, upload, download, posting, updating, networking, dan sebagainya. Variabel penggunaan media dalam penelitian ini diukur dengan menggunakan 5 indikator: (1) kemampuan memilih (selektifitas), (2) kesengajaan (intentionally), (3) pemanfaatan (utilitarianism), (4) keterlibatan (involvement), (5) kemampuan melawan pengaruh (previous to influence). Kelima indikator tersebut dijabarkan dalam 14 item pertanyaan dan hasil selengkapnya ditunjukkan pada tabel berikut.

Dari sebelas jenis media baru yang mungkin tersedia atau dimiliki oleh anak, diketahui bahwa tingkat kepemilikan atau ketersediaan media untuk anak di rumah sebesar 4,675 atau dalam kategori sedang cenderung rendah. Jenis media baru yang banyak tersedia atau dimiliki di rumah antara lain televisi analog, handphone biasa, laptop yang dapat terhubung dengan internet atau dilengkapi modem, dan playstation. Jenis media seperti smartphone, jaringan internet, media player (VCD player, DVD player), dan perangkat video streeming masih jarang tersedia atau dimiliki oleh anak secara pribadi.

Pengunaan media baru yang terus meningkat pada anak-anak di Indonesia tidak jauh berbeda dengan yang terjadi di Pakistan. Hal ini tampak dari hasil penelitian Mahboob Rabbani (2015) yang menyatakan bahwa: "The impact of the Internet on education is important issues that become critical situation for us in recent year. Internet is a very essential part of life for enjoyment and education. It is a very large community which is using internet for pure education but unfortunately we have also a very large number of people including majority of youth and teenager using internet only for enjoyment" (MahboobRabbani et al., 2015).

Berdasarkan data dari hasil penelitian yang berjudul "Keamanan Penggunaan Media Digital pada Anak dan Remaja di Indonesia" yang dilakukan UNICEF dan Kementerian Komunikasi dan Informatika, pengguna internet di Indonesia yang berasal dari kalangan anak-anak dan remaja diprediksi mencapai 30 juta. Penelitian tersebut juga mencatat ada kesenjangan digital yang kuat antara anak dan remaja yang tinggal di perkotaan dengan yang tinggal di pedesaan. Masih berdasarkan hasil penelitian tersebut didapatkan tiga motivasi bagi remaja untuk mengakses internet, yaitu untuk mencari informasi, untuk terhubung dengan teman (lama dan baru) dan untuk hiburan. Pencarian informasi yang dilakukan sering didorong oleh tugas-tugas sekolah, sedangkan penggunaan media sosial dan konten hiburan didorong oleh kebutuhan pribadi (dalam http://kominfo.go.id/). Setyani (2013) the use of social media, twitter, facebook, and blogs as a means of communication is used to provide information, registration, class teachers, search places and volunteer coordination, greetings, live tweets, partnership, sharing photos, communication with other cities, and communication with other accounts. The use of social media as a means of communication for the Akademi Berbagi Surakarta rated effective because can be easily and quickly in disseminating information communicated to audiences without thinking distance, space, and time.

Peningkatan penggunaan media baru tanpa diiringi dengan peningkatan literasi media dapat memicu terjadinya berbagai tindakan sosial menyimpang di kalangan anak-anak. Dengan tersedianya fasilitas game online di sekitar sekolah dapat menyebabkan siswa lebih suka bolos sekolah hanya untuk bermain game online. Siswa yang masih duduk di bangku SD boleh jadi sudah terampil mengirim pesan pendek tentang cinta atau siswa yang meledek gurunya dengan kata-kata yang ditirunya dari pesan di jejaring sosial, dan sebagainya. Banyak faktor yang dapat memperburuk kondisi tersebut, seperti makin longgarnya hubungan sosial antaranggota keluarga dan masyarakat di mana individualisme makin berkembang dan dihormati sebagai bagian dari hak asasi manusia, tingkat literasi media yang masih rendah khususnya pada masyarakat pedesaan, sikap permisif dan toleransi masyarakat yang relatif tinggi terhadap perilaku sosial menyimpang, dan tersedianya berbagai fasilitas komunikasi termasuk berbagai bentuk media baru. 
Tabel 7 Kategori variabel dependen: interaksi sosial anak

\begin{tabular}{|c|c|c|c|c|c|c|c|c|c|}
\hline \multirow{3}{*}{ No. } & \multirow{3}{*}{ Indikator } & \multicolumn{6}{|c|}{ Kategori } & \multirow{3}{*}{ Rerata } & \multirow{3}{*}{ Kategori } \\
\hline & & \multicolumn{2}{|c|}{ Tinggi } & \multicolumn{2}{|c|}{ Sedang } & \multicolumn{2}{|c|}{ Rendah } & & \\
\hline & & $\mathbf{F}$ & $\%$ & $\mathbf{F}$ & $\%$ & $\mathbf{F}$ & $\%$ & & \\
\hline $\mathbf{A}$ & Kerja sama: & & & & & & & & \\
\hline 1 & $\begin{array}{l}\text { Frekuensi komunikasi dengan } \\
\text { orang tua }\end{array}$ & 67 & 83,75 & 10 & 12,5 & 3 & 3,75 & 2,80 & Tinggi \\
\hline 2 & Hal-hal yang diceritakan & 32 & 40 & 24 & 30 & 24 & 30 & 2,10 & Sedang \\
\hline 3 & $\begin{array}{l}\text { Cara menceritakan masalah } \\
\text { pribadi }\end{array}$ & 70 & 87,5 & 8 & 10 & 2 & 2,5 & 2,85 & Tinggi \\
\hline 4 & $\begin{array}{l}\text { Kesediaan membantu pekerjaan } \\
\text { orang tua }\end{array}$ & 49 & 61,25 & 29 & 36,3 & 2 & 2,5 & 2,59 & Tinggi \\
\hline 5 & $\begin{array}{l}\text { Sikap ketika ada saudara yang } \\
\text { sakit }\end{array}$ & 54 & 67,5 & 23 & 28,8 & 3 & 3,75 & 2,64 & Tinggi \\
\hline B & Akomodasi: & & & & & & & & \\
\hline 6 & Mitra bercerita & 45 & 56,25 & 22 & 27,5 & 13 & 16,25 & 2,40 & Tinggi \\
\hline 7 & $\begin{array}{l}\text { Bahasa yang digunakan untuk } \\
\text { berkomunikasi dengan orang tua }\end{array}$ & 9 & 11,25 & 57 & 71,3 & 14 & 17,5 & 1,94 & Sedang \\
\hline 8 & $\begin{array}{l}\text { Bahasa yang digunakan untuk } \\
\text { berkomunikasi dengan teman } \\
\text { sebaya }\end{array}$ & 17 & 21,25 & 47 & 58,8 & 16 & 20 & 2,01 & Sedang \\
\hline 9 & $\begin{array}{l}\text { Bahasa yang digunakan untuk } \\
\text { bekomunikasi melalui handphone }\end{array}$ & 37 & 46,25 & 32 & 40 & 11 & 13,75 & 2,33 & Sedang \\
\hline $\mathbf{C}$ & Kompetisi : & & & & & & & & \\
\hline 10 & $\begin{array}{l}\text { Sikap dalam menghapai teman } \\
\text { yang melakukan kesalahan }\end{array}$ & 43 & 53,75 & 33 & 41,3 & 4 & 5 & 2,49 & Tinggi \\
\hline 11 & $\begin{array}{l}\text { Sikap ketika teman meminjam } \\
\text { barang }\end{array}$ & 52 & 65 & 26 & 32,5 & 2 & 2,5 & 2,63 & Tinggi \\
\hline 12 & $\begin{array}{l}\text { Sikap jika prestasi teman lebih } \\
\text { baik }\end{array}$ & 62 & 77,5 & 14 & 17,5 & 4 & 5 & 2,73 & Tinggi \\
\hline 13 & $\begin{array}{l}\text { Sikap jika melakukan kesalahan } \\
\text { kepada orang lain }\end{array}$ & 46 & 57,5 & 20 & 25 & 14 & 17,5 & 2,40 & Tinggi \\
\hline D & Konflik: & & & & & & & & \\
\hline 14 & Sikap jika kecewa pada orang tua & 39 & 48,75 & 37 & 46,3 & 4 & 5 & 2,44 & Tinggi \\
\hline 15 & $\begin{array}{l}\text { Sikap ketika diminta mengurangi } \\
\text { penggunaan media }\end{array}$ & 52 & 65 & 20 & 25 & 8 & 10 & 2,55 & Tinggi \\
\hline 16 & Sikap ketika dimintai contekan & 49 & 61,25 & 13 & 16,3 & 18 & 22,5 & 2,39 & Tinggi \\
\hline & Jumlah rerata seluruh indikator & & & & & & & 39,26 & \\
\hline & Rerata varibel & & & & & & & 2,45 & Tinggi \\
\hline
\end{tabular}

Sumber: Kuesioner No. 15-30 yang telah diolah 


\section{Pola Interaksi Sosial Anak Usia 8-12 Tahun di Kabupaten Sukoharjo}

Variabel ini diamati dengan menggunakan 4 indikator yaitu interaksi sosial yang bersifat asosiatif yang terdiri dari kerjasama dan akomodasi, serta interaksi sosial yang bersifat disosiatif yang meliputi persaingan dan konflik. Keempat indikator tersebut dijabarkan ke dalam 16 item pertanyaan dan hasil selengkapnya disajikan pada tabel berikut.

Interaksi sosial anak dalam penelitian ini dikelompokkan ke dalam empat bentuk yaitu kerjasama, akomodasi, kompetisi, konflik. Masing-masing indikator tersebut dioperasionalisasikan dalam enam belas item pertanyaan. Data yang diperoleh menunjukkan bahwa rerata skor interaksi sosial anak sebesar 2,45 dari skala 1,0-4,0 yang berarti dalam kategori tinggi atau baik. Dari 16 item pertanyaan yang digunakan sebagai parameter, sebanyak 12 di antaranya rerata skor berada pada kategori tinggi dan 4 item lainnya pada kategori sedang. Hal ini dapat dimaknai sebagai indikasi interaksi sosial anak yang bersifat langsung, sosiabilitasnya tinggi, memiliki kepekaan sosial yang baik, dan dalam berkomunikasi lebih mengutamakan relasi ketimbang isi. Kecenderungan untuk bersikap egalitarian dalam komunikasi ditunjukkan dengan pemilihan bahasa Indonesia dan bahasa Jawa ngoko bukan bahasa Jawa krama yang memiliki stratifikasi.

Interaksi sosial anak bersifat dinamis dan berkembang seiring perkembangan usianya. Salah satu cara yang dapat digunakan untuk membantu mengembangkan interaksi sosial anak adalah melalui pendekatan metode kerja kelompok (Nunik, 2014). Perbedaan penelitian ini dari penelitian Nunik (2014) adalah bahwa dalam penelitian Nunik (2014) interaksi anak TK dikaji dari tiga aspek yaitu kontak sosial, komunikasi, dan kerja sama, sedangkan dalam penelitian ini interaksi sosial anak usia 8-12 tahun dikaji dari bentuk interaksi asosiatif yang terdiri dari kemampuan bekerja sama dan menyesuaikan diri dan bentuk interaksi disosiatif yang terdiri dari kompetisi dan konflik. Penggunaan media baru oleh remaja sub-urban berada dalam kategori heavy user. Sedangkan motif yang paling menonjol adalah motif kognitif, dimana para remaja menjadikan media baru sebagai beragam sumber informasi (Pramiyanti, dkk; 2014).

\section{Pengaruh Penggunaan Media Baru terhadap Pola Interaksi Sosial Anak}

Pengaruh penggunaan media baru terhadap pola interaksi sosial anak usia 8-12 tahun di Kabupaten Sukoharjo berada dalam kategori sedang. Hal tersebut ditunjukkan dengan koefisien korelasi sebesar 0,54 yang berarti korelasi dalam kondisi kuat. Hasil uji signifikansi menunjukkan bahwa korelasi tersebut sinifikan pada derajat kebebasan (degree of freedom) 0,05 . Oleh karena itu, hipotesis yang menyatakan bahwa penggunaan media baru berpengaruh positif dan signifikan terhadap pola interaksi sosial anak usia 8-12 tahun di Kabupaten Sukoharjo dinyatakan diterima kebenaran atau keberlakuannya pada derajat kepercayaan 95\%. Koefisien korelasi antara penggunaan media baru dan pola interaksi sosial anak sebesar 0,54 menunjukkan bahwa penggunaan media baru bukan satu-satunya variabel yang mempengaruhi pola interaksi sosial anak. Interaksi sosial anak dipengaruhi oleh banyak faktor yang meliputi faktor internal dan faktor eksternal yang sering disebut sebagai faktor personal dan faktor situasional. Faktor internal atau faktor yang ada dalam diri anak itu sendiri seperti usia, jenis kelamin, motif, dan keterbukaan. Faktor ekternal atau faktor situasional yaitu faktor yang berasal dari luar anak yang bersangkutan seperti lingkungan, situasi, kondisi, karakteristik teman, dan sebagainya.

Interaksi sosial adalah salah satu ciri utama manusia sebagai makhluk sosial dan proses ini berjalan secara dinamis seiring pertumbuhan dan perkembangan hidup individu yang bersangkutan. Pertumbuhan diartikan sebagai perubahan yang bersifat kuantitatif, yaitu 
bertambahnya ukuran dan struktur sedang perkembangan diartikan sebagai perubahan kualitatif yaitu perubahan yang progresif, koheren, dan teratur. Irwanto et al. (1996:39-43) membagi perkembangan manusia dalam 8 fase atau periode, yaitu: (a) periode dalam kandungan, (b) periode bayi, (c) periode kanak-kanak awal, (d) periode kanak-kanak akhir, (e) periode pubertas, (f) periode remaja, (g) periode dewasa awal, dan (h) periode dewasa akhir. Periode kanak-kanak akhir (late childhood) dimulai sekitar umur 6 tahun hingga 14-15 tahun. Pada masa ini anak mulai membandingkan segala sesuatu di rumahnya dengan yang ditemuinya di luar, norma-normanya menjadi relatif, suka membantah dan membanding-bandingkan (Irwanto et al., 1996:44). Perkembangan pada usia remaja menunjukkan bahwa sosialisasi bukan saja diperlukan demi untuk memenuhi kebutuhan kepribadiannya, tetapi mengandung maksud untuk memenuhi kebutuhan bersama atau kebutuhan orang lain. Interaksi sosial atau aksi dan reaksi menurut Irwanto et al. (1996:258-269) dipengaruhi oleh persepsi sosial, persepsi diri, atraksi interpersonal, sikap, dan prasangka.

Interaksi sosial anak bersifat dinamis dan dapat dikembangkan melalui berbagai cara. Salah satu cara yang dapat digunakan adalah pendekatan metode kerja kelompok. Hasil penelitian Ririhirawati (2014) terhadap siswa Taman Kanak-Kanak di Pungging Kabupaten Mojokerto menyimpulkan bahwa pendekatan kerja kelompok dapat digunakan untuk meningkatkan kemampuan interaksi sosial anak. Hal ini dimungkinkan karena dalam satu kerja kelompok ada aspek kerja sama, komunikasi, kontak sosial, konflik, dan kompetisi sebagai bentuk-bentuk interaksi sosial yang dapat berlangsung bersama-sama. Budiman (2016) menyatakan bahwa media baru khususnya media sosial sangat berpengaruh terhadap interaksi sosial anak. Bentukbentuk pengaruh dimaksud meliputi pengaruh positif dan negatif. Pengaruh positif media sosial antara lain: (a) membuka kepeduliaan terhadap sesama saat terjadi musibah atau peristiwa buruk lainnya, (b) memperluas jaringan pertemanan di manapun dia berada sehingga membuat interaksi sosial lebih luas lagi, dan (c) memudahkan berkomunikasi sehingga memudahkan juga untuk masyarakat berinteraksi satu dengan lainnya. Sementara itu, pengaruh negatif sosial media, antara lain: (a) membuat orang semakin malas untuk berbicara dimana setiap bangun tidur 2 dari 5 orang di dunia akan mengecek sosial medianya terlebih dahulu sebelum memulai beraktivitas, dan rata-rata setiap orang di dunia menghabiskan waktu kurang lebih 2 jam untuk sosial media. Hal tersebut menyebabkan orang lebih malas untuk berinteraksi dengan orang sekitar dan lebih memilih untuk berinteraksi dengan orang yang dikenalnya di sosial media, (b) membuat orang menjadi kaku khususnya cyberbullying membuat korban menjadi defensif dan kaku, terkadang korban lebih memilih menghindari kegiatan sosial karena takut dijahili, (c) meningkatnya candaan yang tidak baik atau tidak bertanggung jawab. Sindiran atau kritik memang baik untuk membangun orang lain namun jika dikemukakan secara kasar maka hal tersebut dapat melukai hati seseorang. Demikian juga candaan yang bernada porno atau mengandung pornografi juga tidak baik dan dapat merusak interaksi sosial yang sudah terbina sebelumnya, dan (d) media sosial mendekatkan dengan yang jauh, tetapi menjauhkan dengan yang dekat. Dalam berinteraksi sosial tentu orang ingin memilih dengan siapa berinteraksi, fungsi utama sosial media memang menghubungkan siapa saja termasuk yang jauh, namun tanpa disadari pengguna media sosial seringkali lebih memilih untuk berinteraksi dengan orang yang hanya dikenal lewat sosial media dan melupakan orang yang dekat seperti teman sekolah, tetangga, atau keluarga yang tinggal dalam satu rumah.

\section{SIMPULAN}

Hasil penelitian menunjukkan bahwa tingkat penggunaan media baru di kalangan anak usia 8-12 tahun di Kabupaten Sukoharjo dalam kategori sedang $(1,89)$ dan interaksi sosialnya dalam kategori tinggi $(2,45)$. Asumsi yang menyatakan bahwa semakin tinggi penggunaan 
media baru maka interaksi sosial anak akan cenderung semakin rendah dapat diterima kebenarannya dengan koefisien korelasi sebesar 0,54 pada derajat kebebasan 0,05 atau tingkat kepercayaan $95 \%$.

\section{DAFTAR PUSTAKA}

Arikunto, Suharsimi. 2006. Prosedur Penelitian Suatu Pendekatan Praktik, Jakarta: Rineka Cipta.

Budiman. 2016. Makalah Pengaruh Sosial Media Terhadap Interaksi Sosial Masyarakat. http:// www.c3budiman.lol/2016/06/14/makalah-pengaruh-sosial-media-terhadap-interaksisosial-masyarakat/?i=1 diakses 24 Oktober 2016, 15:44 WIB.

Effendy, Onong Uchyana. 2000. Ilmu, Teori, dan Filsafat Komunikasi.Bandung: PT Citra Aditya Bakti.

Irwanto, dkk. 1996. Psikologi Umum: Buku Panduan Mahasiswa. Jakarta: PT Gramedia Pustaka Utama.

Kompasiana. 2010. Memahami Istilah-Istilah Baru New Media. http://new-media.kompasiana. com/2010/02/05/memahami-istilah-media-baru-new-media/

Littlejohn, Stephen W. 1999. Theories of Human Communication. 6th Edition. Belmont CA: Wadsworth Publishing Company.

Mahboob Rabbani, et al. 2015. Impact of Social Networking Websites on Students learning. New Media and Mass Communication ISSN 2224-3267 (Paper) ISSN 2224-3275 (Online). Vol.44, 2015. www.iiste.org. Diakses tanggal 28 Januari 2016 pukul 13:56 WIB

Mc Quail, Denis. 2006. Teori Komunikasi Massa Suatu Pengantar. Alih bahasa oleh Agus Dharma dan Aminudin Ram. Jakarta: Erlangga.

Nunik. 2013. Peningkatan Kemampuan Interaksi Sosial Anak Melalui Metode Kerja Kelompok Pada Kelompok B Tk Anata Pura Petimbe. Skripsi. Program Studi PG PAUD, Jurusan Ilmu Pendidikan, Fakultas Keguruan dan Ilmu Pendidikan, Universitas Tadulako, No. Stambuk: A 45109041.

Pramiyanti, Alila. Idola Perdini Putri. Reni Nureni. 2014.Motif Remaja Dalam Menggunakan Media Baru (Studi Pada Remaja di Daerah Sub-Urban Kota Bandung). Jurnal KomuniTi, Vol. VI, No. 2 September 2014. https://publikasiilmiah.ums.ac.id/bitstream/ handle/11617/5876/1KomuniTi.Volume20VI No.20 September 2014.pdf sequence $=1$. Diakes 12 Okt 2016 pukul 15.05

Rahayu, Nuryani Tri. 2009. Tayangan Hiburan TV dan Penerimaan Budaya Pop. Jurnal Ilmiah SCRIPTURA. Surabaya: Jurusan Ilmu Komunikasi Fakultas Ilmu Komunikasi Universitas Kristen Petra.

Ririhirawati, Dyan. 2014. Pengaruh Metode Kerja Kelompok terhadap Kemampuan Interaksi anak TK Al-Falah Punggong Kabupaten Mojokerto. Sociodev. Jurnal S.1 Sosiatri Vol3 No.3 November 2014. http://jurnafis.untan.ac.id. Diakses 19 Oktober, 16:12 WIB.

Sari Lisdian Andarbeni dan Elisabeth Christiana. 2013. Study on The ability of Social Interaction In A Group OfChildren Activities Project Method in Tk Plus Al-Falah Pungging Mojokerto. Jurnal BK Unesa. Volume 04 Nomor 01 Tahun 2013. 285-292.

Setyani, Novia Ika. 2013. Penggunaan Media Sosial sebagai Sarana Komunikasi bagi 
Komunitas (Studi Deskriptif Kualitatif Penggunaan Media Sosial Twitter, Facebook, dan Blog sebagai Sarana Komunikasi bagi Komunitas Akademi Berbagi Surakarta). Jurnal Komunikasi. abdul Kahar. https://abdulkaharkimia. files.wordpress.com/2013/12/jurnalnovia-ika.pdf.

Singarimbun, Masri dan Sofian Effendi. 1995. Metode Penelitian Survei. Jakarta:. Pustaka LP3ES Indonesia.

Soekanto, Soerjono. 2001. Sosiologi Suatu Pengantar. Jakarta: PT Raja Grafindo Persada.

Teresa Orange dan Louis O'flynn. 2005. The media diet for kids. New York : David McCay.

YPMA. 2010. Kidia; Kritisi Media untuk Anak. No. 25 Edisi Oktober-November 2010. Jakarta: Yayasan Pengembangan Media Anak kerja sama dengan UNICEF. 